\title{
Accounting
}

\section{How does liquidity influence bank profitability? A panel data approach}

\author{
Thu-Trang Thi Doan ${ }^{\mathrm{a}^{*}}$ and Toan Ngoc Bui ${ }^{\mathrm{a}}$
}

${ }^{a}$ Faculty of Finance and Banking, Industrial University of Ho Chi Minh City (IUH), Vietnam

\begin{tabular}{l}
\hline C H R O N I C L E \\
\hline Article history: \\
Received: July 2, 2020 \\
Received in revised format: \\
September 302020 \\
Accepted: October 8, 2020 \\
Available online: \\
October 12, 2020 \\
\hline Keywords: \\
GMM estimation \\
Liquidity \\
Panel data \\
Return on assets \\
Vietnam
\end{tabular}

\section{A B S T R A C T}

\begin{abstract}
This study investigates the impact of liquidity on bank profitability. Particularly, bank profitability is measured by return on assets (ROA) while liquid assets to total assets (LATA) and total loans to total deposits (TLTD) are indicators of bank liquidity. A panel data of 26 Vietnamese commercial banks are obtained over the period 2013-2018. The GMM estimation is adopted to test the significant effect of liquidity on profitability of Vietnamese commercial banks. The results reveal that profitability (ROA) was negatively influenced by liquid asset ratio (LATA) and positively correlated to loan-to-deposit ratio (TLTD). Further, bank profitability was also affected by macroeconomic control variables like economic growth (EG) and inflation (INF). The results are not only essential for bank managers but also provide scholars a valuable reference.
\end{abstract}

(C) 2021 by the authors; licensee Growing Science, Canada

\section{Introduction}

Bank liquidity has received more attention since the global financial crisis in 2007 . This is because the liquidity exerts a significant impact on rights of depositors (Wasiuzzaman \& Tarmizi, 2010), stability of financial system (Kumar \& Yadav, 2013), most notably bank profitability (Bourke, 1989; Molyneux et al., 1994). More than that, the casual relationship between liquidity and bank profitability has been examined in a big number of empirical studies. However, there are still different views on this correlation. In specific, it is stated that liquidity helps banks withstand shocks to the economy, thereby boosting their performance (Bordeleau \& Graham, 2010; Ibe, 2013; Lartey et al., 2013; Nimer et al., 2013; Rasul, 2013; Bui, 2019a; Nguyen et al., 2020). Nevertheless, some scholars reported that banks with too much liquid assets may lose some business opportunities, causing a fall in their performance (Eljelly, 2004; Olagunju et al., 2011; Nimer et al., 2013; Nimer et al., 2015). Moreover, there are still various measurements of liquidity. Indeed, liquidity is measured by liquid assets to total assets (LATA) in most empirical studies while Ibe (2013), Rasul (2013), Shah et al. (2018) employed loan-to-deposit ratio (TLTD) as a proxy of liquidity, which is frequently adopted in many studies because it can demonstrate liquidity risk. The correlation between liquidity and bank profitability is thus an interesting research topic for the analysis and essential specifically for countries with a nascent banking sector like Vietnam. By this study, the author examines the influence of liquidity on bank profitability in Vietnam. It is expected to reveal unprecedented findings which are useful to bank management as well as researchers.

\footnotetext{
* Corresponding author.

E-mail address: doanthithutrang@iuh.edu.vn (T.-T. T. Doan)
} 


\section{Literature review and research hypothesis}

Liquidity can be referred to how assets or shares can be converted into cash. To banking sector, liquidity means the ability to meet the withdrawal needs of customers (Wasiuzzaman \& Tarmizi, 2010). Liquidity plays a key role to banking sector by ensuring benefits of depositors (Wasiuzzaman \& Tarmizi, 2010), helping stabilize financial system (Kumar \& Yadav, 2013), and more notably boosting bank profitability (Bourke, 1989; Molyneux et al., 1994). Regarding the measurement, the ratio of liquid assets by total assets (LATA) and total loans by total deposits (TLTD) are adopted as proxy of bank liquidity.

\subsection{The impact of liquidity ratio (LATA) on bank profitability (ROA)}

Liquid assets include cash and equivalent, cash reverse at the central bank, cash and gold kept at or loaned to other credit institutions (Bordeleau \& Graham, 2010; Rasul, 2013). The nature of bank operation is the frequent use of short-term deposits of customers for granting long-term loans. Therefore, it is necessary for banks to possess sufficient liquid assets to guarantee safety, minimize bankruptcy risk, and more importantly improve profitability. The influence of liquid asset ratio on bank profitability has been reported in a number of empirical studies. For instance, Bordeleau and Graham (2010), Ibe (2013), Lartey et al. (2013), Nimer et al. (2013), Rasul (2013) found the positive effect of liquidity on bank profitability. Accordingly, the maintenance of liquidity at a mild level can help ensure the safety in bank operation as well as reduce external cost for the guaranteed liquidity, which in turn boosts the performance. However, it is believed that liquidity can exert a negative impact on bank profitability by some scholars like Eljelly (2004), Olagunju et al. (2011), Nimer et al. (2013), Nimer et al. (2015). This shows that more liquid liabilities may take away more business opportunities from banks, leading to a risk of decreasing profits. In the period studied, Vietnam just experienced the global financial crisis, so liquidity attracts more attention from its banking sector. Also, to guarantee a secured operation, Vietnamese banks have concentrated on keeping a high liquidity ratio. This may negatively affect the performance, but greatly contribute in bringing a safe business. Based on this, this study has formulated the hypothesis as follows:

$\mathrm{H}_{1}$ : The liquidity ratio (LATA) has a negative impact on bank profitability (ROA).

\subsection{The impact of loan-to-deposit ratio (TLTD) on bank profitability (ROA)}

A higher loan-to-deposit ratio demonstrates a lower liquidity, and vice versa. Nevertheless, this ratio reflects the variance between a bank's major income from loans and the actual cost for raising capital (Shah et al., 2018). Therefore, bank profitability can be improved with a big variance. This impact has been revealed in the studies of Ibe (2013) and Rasul (2013). However, if the ratio of total loans to total deposits is too high, more liquidity risks may arise, which gives a considerable fall in the future performance. In the period studied, Vietnam has just overcome the global financial crisis, social influence banking sector plays a vital role in supplying capital to the economy in order to enhance businesses. Thus, total loans will be improved and focused mainly on manufacturing. Then, the economy can be recovered and bank profitability can be improved. Hence, the hypothesis is developed as follows:

\section{$\mathrm{H}_{2}$ : The loan-to-deposit ratio (TLTD) has a positive impact on bank profitability (ROA).}

\section{Methodology}

The primary source of data is obtained from financial reports of 26 commercial banks in Vietnam from 2013 to 2018. This study investigates the influence of liquidity on bank profitability. To achieve this objective, the author uses the Generalized Method of Moment (GMM) for the estimation, which is expected to control potential endogeneity issues and repair violated assumptions (Bui, 2020a, 2020b; Bui \& Doan, 2020; Doan, 2020a, 2020b; Doan \& Bui, 2020). Based on what is presented in Section 2, the author starts to develop the model for the study. Accordingly, the dependent variable of profitability is measured by return on assets (ROA). The ratios of liquid assets to total assets (LATA) and total loans to total deposits (TLTD) are employed as independent variables of liquidity. Further, the macroeconomic factors including economic growth (EG) and inflation (INF) are adopted as control variables, which are really important in the research model. These are two control variables that represent the macroeconomics of each country (Bui, 2019b; Nguyen \& Bui, 2019). This is because bank profitability is not only affected by bank-specific determinants but also significantly correlated to macroeconomic factors (Kosmidou, 2008). Thus, the proposed model takes the following equation:

$$
\mathrm{ROA}_{\mathrm{it}}=\beta_{0}+\beta_{1} \mathrm{LATA}_{\mathrm{it}}+\beta_{2} \mathrm{TLTD}_{\mathrm{it}}+\beta_{3} \mathrm{EG}_{\mathrm{t}}+\beta_{4} \mathrm{INF}_{\mathrm{t}}+\varepsilon_{\mathrm{it}}
$$

where:

Dependent variable (ROA): Profitability (return on assets).

Independent variables:

INF: Inflation.

LATA: Liquid assets / Total assets. $\varepsilon$ : error term.

TLTD: Total loans / Total deposits. $\beta_{\mathrm{i}}$ : coefficients.

Control variables:

$\beta_{0}$ : constant.

EG: Economic growth. 


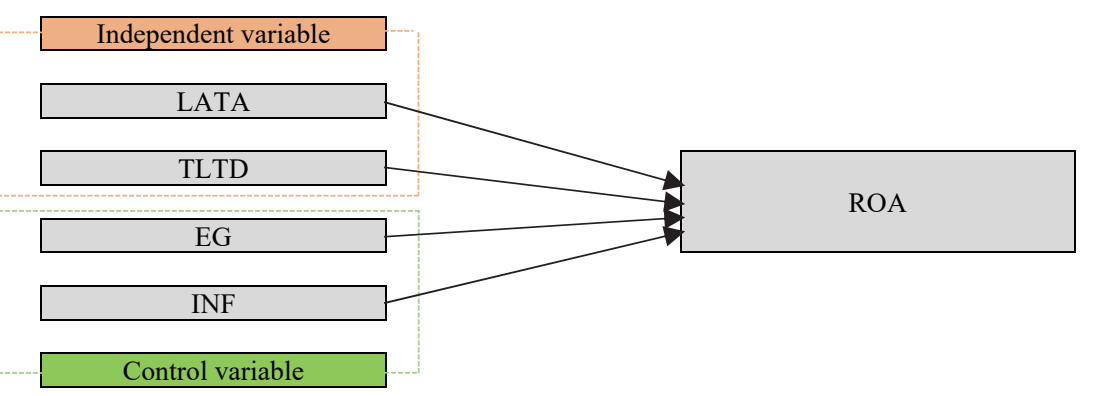

Fig 1. Suggested research model

\section{Results}

The data obtained from the 26 Vietnamese commercial banks in the 2013-2018 period together and the variables are presented in Table 1 as follows:

\section{Table 1}

Descriptive statistics

\begin{tabular}{llc}
\multicolumn{1}{c}{ Variable } & Mean & Min \\
\hline Profitability (ROA) & 0.006 & 0.001 \\
Liquid assets / Total assets (LATA) & 0.158 & 0.045 \\
Total loans / Total deposits (TLTD) & 0.666 & 0.026 \\
Economic growth (EG) & 0.064 & 0.415 \\
Inflation (INF) & 0.037 & 0.054 \\
\hline
\end{tabular}

The correlation among the variables is demonstrated in Table 2.

Table 2

Variable correlation

\begin{tabular}{lcccc}
\hline & ROA & LATA & TLTD & EG \\
\hline ROA & 1.000 & & & \\
LATA & -0.085 & 1.000 & 1.000 & \\
TLTD & 0.386 & -0.524 & 0.294 & 1.000 \\
EG & 0.121 & -0.246 & -0.155 & -0.720 \\
INF & 0.073 & 0.250 & & 1.000 \\
\hline
\end{tabular}

Table 2 shows that LATA is negatively correlated to ROA while the other independent variables are positively associated with ROA. The model will be estimated by adopting fundamental analysis methods using panel data, namely Pooled Regression model (Pooled OLS), Fixed effects model (FEM) and Random effects model (REM).

\section{Table 3}

Results of testing the model using Pooled OLS, FEM, REM

\begin{tabular}{|c|c|c|c|}
\hline \multicolumn{4}{|c|}{ Dependent Variable: Profitability (ROA) } \\
\hline ROA & Pooled OLS & FEM & REM \\
\hline Constant & $-0.020^{* * *}$ & $-0.024^{* * *}$ & $-0.023^{* * *}$ \\
\hline LATA & 0.009 & $0.024^{* * *}$ & $0.020^{* * *}$ \\
\hline TLTD & $0.015^{* * *}$ & $0.026^{* * *}$ & $0.023^{* * *}$ \\
\hline EG & $0.194^{* *}$ & 0.112 & $0.138^{* *}$ \\
\hline INF & $0.077^{* *}$ & $0.056^{* * *}$ & $0.062^{* * *}$ \\
\hline R-squared & $20.03 \%$ & $37.46 \%$ & $37.27 \%$ \\
\hline Significance level & $F(4,151)=9.46$ & $F(4,126)=18.87$ & Wald chi2 $(4)=74.11$ \\
\hline F test & & $F(25,126)=9.93$ & \\
\hline Hausman test & & $\operatorname{chi} 2(4)=3.80$ & \\
\hline
\end{tabular}

Note: ${ }^{* *}$ and ${ }^{* * *}$ indicate significance at the $5 \%$ and $1 \%$ level, respectively.

It can be seen from Table 3 that the Random effects model $(\mathrm{REM})$ is more appropriate when $\mathrm{F}$-test $(\mathrm{F}(25,126)=9.93)$ result are significant at the $1 \%$ level. However, Hausman test (chi2 $(4)=3.80)$ shows no significance. Accordingly, the estimated result using the Random effects model (REM) is chosen for testing regression hypotheses. 


\section{Table 4}

Results of testing research model

\begin{tabular}{|c|c|c|c|}
\hline \multicolumn{2}{|c|}{ Multicollinearity test } & \multirow{2}{*}{ Breusch and Pagan Lagrangian multiplier test } & \multirow{2}{*}{ Wooldridge test } \\
\hline Variable & VIF & & \\
\hline LATA & 1.44 & \multirow{5}{*}{$\begin{array}{l}\text { chibar } 2(01)=125.26 \\
\text { Prob }>\text { chi } 2=0.000^{* * *}\end{array}$} & \multirow{5}{*}{$\begin{array}{l}\mathrm{F}(1,25)=13.994 \\
\text { Prob }>\mathrm{F}=0.001^{* * *}\end{array}$} \\
\hline TLTD & 1.47 & & \\
\hline EG & 2.24 & & \\
\hline INF & 2.15 & & \\
\hline $\mathrm{Me}$ & & & \\
\hline
\end{tabular}

The results show that there is no serious problem of multicollinearity. However, heteroscedasticity and autocorrelation really exist at the 1\% (Table 4). To avoid these issues, the GMM is adopted for the estimation. The GMM is also superior in controlling potential endogeneity issues.

\section{Table 5}

GMM estimation results

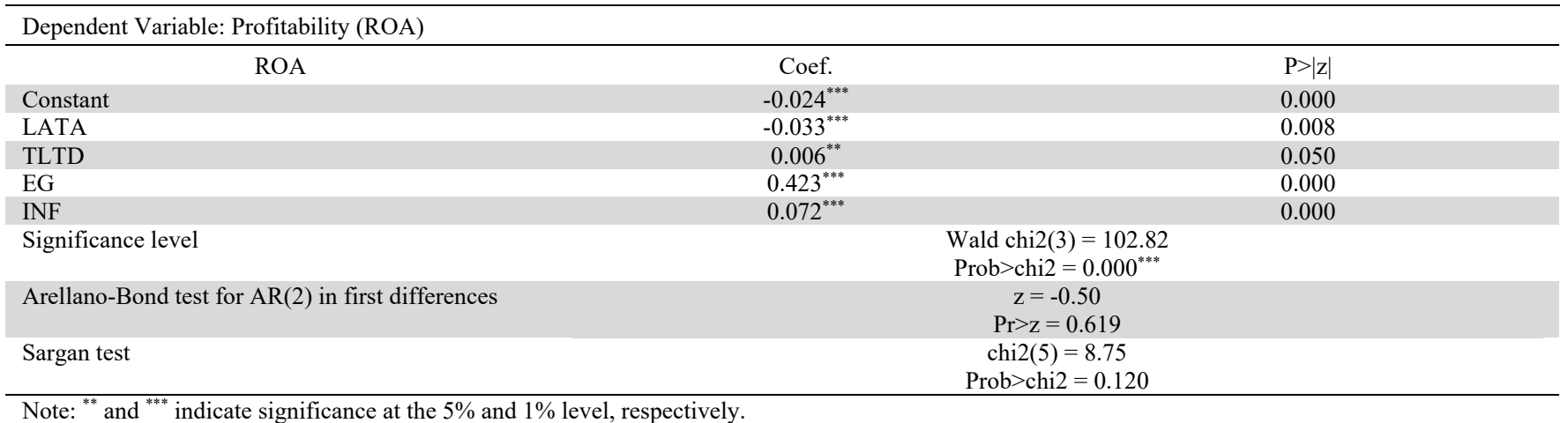

Table 5 reveals that the result of model estimation is significant at the $1 \%$ level. Also, Sargan test and Arellano-Bond test for AR(2) in first differences are appropriate. Thus, the results of the GMM estimation are valid. It can be concluded that liquidity significantly influences bank profitability. Particularly, profitability (ROA) is negatively affected by LATA $(\beta=-0.033)$ at the $1 \%$ level of significance while it is positively influenced by TLTD $(\beta=0.006)$ at the $5 \%$ significance level. Besides, it can be found that the control variable EG $(\beta=0.423)$ and INF $(\beta=0.072)$ are significant to profitability (ROA) at the $1 \%$ level. This reveals that together with liquidity, bank profitability is significantly affected by macroeconomic variables, which corroborates what Kosmidou (2008) reported previously.

Therefore, the estimated result of the model is written in the following equation:

$$
\mathrm{ROA}_{\mathrm{it}}=-0.024-0.033 \mathrm{LATA}_{\mathrm{it}}+0.006 \mathrm{TLTD}_{\mathrm{it}}+0.423 \mathrm{EG}_{\mathrm{t}}+0.072 \mathrm{INF}_{\mathrm{t}}+\varepsilon_{\mathrm{it}}
$$

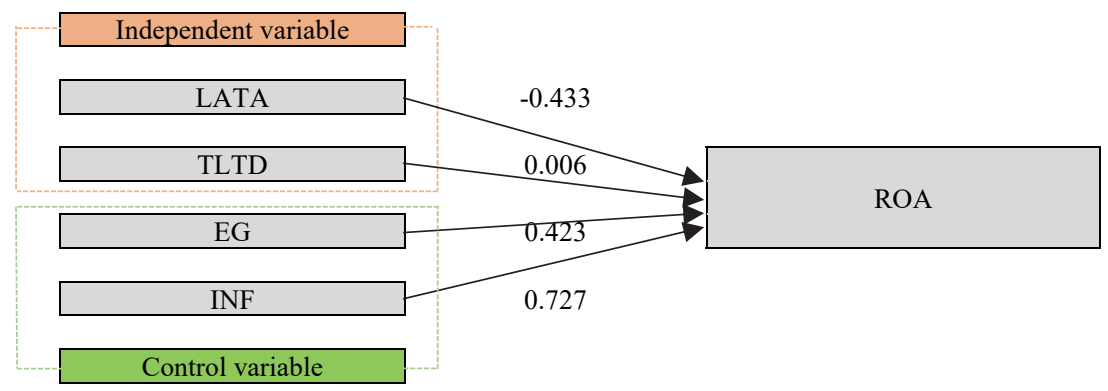

Fig 2. Results of the coefficient estimation

Table 6

Result of hypothesis testing

\begin{tabular}{ccc}
\hline No & Hypothesis & Result \\
\hline $\mathrm{H}_{1}$ & LATA $\Rightarrow$ ROA & Accepted \\
$\mathrm{H}_{2}$ & TLTD $\Rightarrow$ ROA & Accepted \\
\hline
\end{tabular}


- The impact of liquidity ratio (LATA) on bank profitability (ROA): The study reveals the negative relationship between LATA and ROA. This means that too high liquidity may deprive banks of more business opportunities, give a rise in cost while decreasing profits, and more importantly reducing bank profitability. This is in line with the actual context of Vietnam economy, which just witnessed many difficulties caused by the global financial crisis. To guarantee a secured business in this context, it is straightforward for banks to maintain a high liquidity ratio. This finding corroborates what have been reported by Eljelly (2004), Olagunju et al. (2011), Nimer et al. (2013), and Nimer et al. (2015).

- The impact of loan-to-deposit ratio (TLTD) on bank profitability (ROA): It can be found that TLTD is positively related to ROA. This is in line with the findings of Ibe (2013) and Rasul (2013). The rise in the ratio of total loans to total deposits gives an improvement in income received from loans together with a fall in cost of deposit mobilization, so it is obvious that bank profitability will increase. In the period studied, Vietnam economy has just experienced a hard time due to the negative washback of global financial crisis, so banking sector is an essential supplier of capital to the economy, which is mainly into manufacturing. Therefore, total loans are gradually improved, which is the major reason of the improvements in bank profitability. However, the loan-to-deposit ratio should be kept at a mild level. Especially, banks need to invest their loans to low-risk sectors in order to minimize liquidity risk as well as boost profitability.

\section{Conclusion}

The study has analyzed the impact of liquidity on bank profitability in Vietnam. The panel data have been collected from 26 Vietnamese commercial banks in the 2013-2018 period. The study adopts the GMM for the analysis. The results have revealed that liquidity exerts a significant effect on bank profitability. In specific, profitability is negatively correlated to liquidity ratio while the ratio of total loans to total deposits positively affects profitability. Moreover, the profitability was considerably influenced by macroeconomic control variables including economic growth and inflation. The findings provide bank management essential guideline in the aim of maintaining a secured operation and improving profits. The study is a useful reference to researchers.

\section{References}

Bordeleau, E., \& Graham, C. (2010). The Impact of Liquidity on Bank Profitability. Bank of Canada Working Paper, 2010-38.

Bourke, P. (1989). Concentration and other determinants of bank profitability in Europe, North America, and Australia. Journal of Banking and Finance, 13, 65-79.

Bui, T.N. (2019a). The role of financial development in the Vietnam economy. WSEAS Transactions on Business and Economics, 16, 471-476.

Bui, T.N. (2019b). Inflation and stock index: Evidence from Vietnam. Journal of Management Information and Decision Science, 22(4), 408-414.

Bui, T.N. (2020a). How do financial leverage and supply chain finance influence firm performance? Evidence from construction sector. Uncertain Supply Chain Management, 8(2), 285-290.

Bui, T.N. (2020b). Supply chain finance, financial development and profitability of real estate firms in Vietnam. Uncertain Supply Chain Management, 8(1), 37-42.

Bui, T.N., \& Doan, T.T.T. (2020). Factors influencing supply chain finance of real estate sector: Evidence using gmm estimation. Uncertain Supply Chain Management, 8(3), 627-632.

Doan, T.T.T. (2020a). Determinants of financing decisions: Evidence using GMM estimation. Accounting, 6(5), 681-686.

Doan, T.T.T. (2020b). The effect of cash holdings on firm performance: Evidence from Vietnam listed firms. Accounting, 6(5), 721-726.

Doan, T.T.T., \& Bui, T.N. (2020). Nonlinear impact of supply chain finance on the performance of seafood firms: A case study from Vietnam. Uncertain Supply Chain Management, 8(2), 267-272.

Eljelly, A. (2004). The cyclical behavior of optimal bank capital. Journal of Banking and Finance, 28(3), 1469-1498.

Ibe, S.O. (2013). The Impact of Liquidity Management on the Profitability of Banks in Nigeria. Journal of Finance and Bank Management, 1(1), 37-48.

Kosmidou, K. (2008). The determinants of banks' profits in Greece during the period of EU financial integration. Journal of Economic Literature, 34(3), 146-159.

Kumar, S., \& Yadav, S. (2013). Liquidity management and commercial banks' profitability. International Research Journal of Finance and Economics, 5(8), 226-241.

Lartey, V.C., Antwi, S., \& Boadi, E.K. (2013). The relationship between liquidity and profitability of listed banks in Ghana. International Journal of Business and Social Science, 4(3), 48-56.

Molyneux, P., Lloyd-Williams, D.M., \& Thornton, J. (1994). Competitive Conditions in European banking. Journal of Banking and Finance, 18(3), 445-459.

Nguyen, M.L.T., \& Bui, T.N. (2019). Stock market, real estate market, and economic growth: An ARDL approach. Investment Management and Financial Innovations, 16(4), 290-302.

Nguyen, M.L.T., Xuan, P.T.T., \& Bui, T.N. (2020). Causal relationship between banking system development and real estate market. Management Science Letters, 10(1), 41-52. 
Nimer, M.A., Warrad, L., \& Omari, R.A. (2013). The impact of liquidity on Jordanian banks profitability through return on assets. Interdisciplinary Journal of Contemporary Research in Business, 5(7), 70-76.

Nimer, M.A., Warrad, L., \& Omari, R.A. (2015). The impact of liquidity on Jordanian banks profitability through return on assets. European Journal of Business and Management, 7(7), 229-232.

Olagunju, A., David, A.O., \& Samuel, O.O. (2011). Liquidity management and commercial banks' profitability in Nigeria. Research Journal of Finance and Accounting, 2(7), 24-38.

Rasul, L. (2013). Impact of liquidity on Islamic banks' profitability: Evidence from Bangladesh. ECONOMICA, 9(2), 23-36.

Wasiuzzaman, S., \& Tarmizi, H. (2010). Profitability of Islamic banks in Malaysia: An empirical analysis. Journal of Islamic Economics, Banking and Finance, 6(4), 53-68.

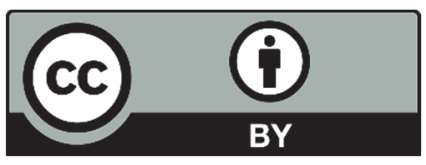

(C) 2021 by the authors; licensee Growing Science, Canada. This is an open access article distributed under the terms and conditions of the Creative Commons Attribution (CC-BY) license (http://creativecommons.org/licenses/by/4.0/). 